Article

\title{
Interaction of Vibrio to Biotic and Abiotic Surfaces: Relationship between Hydrophobicity, Cell Adherence, Biofilm Production, and Cytotoxic Activity
}

\author{
Faouzi Lamari ${ }^{1}$, Sadok Khouadja ${ }^{1}$ and Sami Rtimi ${ }^{2, *}$ (D) \\ 1 Laboratory of Analysis, Treatment and Valorization of Environment Polluants and Products, \\ Faculty of Pharmacy, Monastir University, Monastir 5000, Tunisia; lamari.faouzi@gmail.com (F.L.); \\ Khouadja_sadok@yahoo.fr (S.K.) \\ 2 EPFL-STI-IMX-LTP, Ecole Polytechnique fédérale de Lausanne, Lausanne CH-1015, Switzerland \\ * Correspondence: sami.rtimi@epfl.ch; Tel: +41-21-693-68-03
}

Received: 12 November 2018; Accepted: 10 December 2018; Published: 19 December 2018

\begin{abstract}
Vibrio parahaemolyticus and Vibrio alginolyticus are important pathogenic agents for both humans and aquatic animals. Twenty-five bacterial strains were isolated from infected sea bass (Dicentrarchus labrax) on thiosulfate citrate bile salts sucrose (TCBS) agar plates. For the species-specific detection of $V$. alginolyticus and $V$. parahaemolyticus, a multiplex PCR assay using two collagenase-targeted primer pairs allows the detection of four strains of $V$. parahaemolyticus and three strains of $V$. alginolyticus. The seven identified isolates were partitioned for capsule production, hydrophobicity, adherence, biofilm formation, invasion, and cytotoxicity against Hep-2 cells. Two V. parahaemolyticus (Spa2 and Spa3) and one V. alginolyticus (Va01) were capsule producers developing almost black colonies on CRA, they showed a strong hydrophobicity using bacterial adhesion to hydrocarbons test (BATH), and were able to produce high biofilm. Isolates were able to adhere and invade Hep-2 cells and exhibited dissimilar levels of cytotoxicity in epithelial cells. This study shows the strong relationship between adhesion, biofilm formation, invasion and the cytotoxicity of Vibrio strains. Thus, we found a strong and significant positive correlation between different virulence properties of these isolates. The present study shows that bacterial contact with the cells as well as adhesion and invasion are essential steps to induce cytotoxicity. However, the invasion is seen to be a post adherence event.
\end{abstract}

Keywords: Vibrio; hydrophobicity; adherence; cytotoxicity; invasion; cells

\section{Introduction}

World production of sea bass farming is a growing and intensive marine fish farming in a quite small volume of water. This leads to diverse fish diseases. Bacterial infections have become one of the major problems causing fish morbidity and mortality [1]. Several studies reported that vibrios are important pathogens for animals cultivated in aquaculture [2-4]. Vibrio alginolyticus and Vibrio parahaemolyticus are associated with epidemic vibriosis resulting in high death percentages of cultured aquatic animals [2]. V. alginolyticus is an opportunistic pathogen for marine organisms including mollusks, fish, cnidarians, crustaceans, and sea turtles [5]. It has been described that this organism is responsible for septicaemia in sea bream (Sparus aurata) and exophthalmia and corneal opaqueness in grouper of Epinephelus malabaricus [2]. In addition, this bacterium can be pathogenic for humans and infects wounds and causes ear infections following contact with $V$. alginolyticus-containing seawater [6]. V. parahaemolyticus has been reported to cause gastroenteritis [7]. Vibrios show virulent 
behavior associated with the generation of extracellular products (ECPs) infections [3,8]. In addition, virulence of pathogenic Vibrio strains isolated from fish has been shown to be related to their ability to carry virulence genes such as collagenase [9]. Recently, Ref. [10] reported that V. parahaemolyticus and $V$. alginolyticus produce metalloproteases collagenase, causing degradation of conjunctive tissue through destruction of the basement membrane by digestion of type IV collagen. They use distinct strategies to adhere to their hosts and invade and/or kill the host cell [11].

Adherence of bacteria to host cells is considered the first step for biofilm formation. Cell invasion is a strong feature linked to the pathogenicity of bacteria. The invading entero-invasive bacteria stimulate the mucosal inflammation causing damage to the host. It is likely that factor such as the presence of surface hydrophobicity plays a role in enabling bacteria to attach to a biotic or abiotic surface and to form biofilms. Combined with adhesion ability, the hydrophobicity is related with biofilm formation [12]. Moreover, it has been shown that the polysaccharide capsule is considered the major determinants in pathogen virulence [13]. It is probable that the capsular polysaccharide, when produced in high amounts, alleviates cells' adhesion to epithelia [14]. Other authors reported capsule production allows the bacterium to develop at the infection site [15] and, through its biopolymer components, contributes to the formation of biofilm [16]. Once bacteria become embedded in the extracellular matrix of biofilm, this increases the resistance and improves resistance to antibiotics and disinfectants due to delayed penetration of antimicrobial agents [17]. Several authors reported that Vibrio can form biofilm on various aquaculture installations and colonize abiotic surfaces and can attach to suspended particulate matter, zooplankton, and shellfish $[18,19]$.

Conventional culture-based and biochemical-based methods may fail to detect Vibrio and they are laborious and time-consuming [20]. However, the application of the polymerase chain reaction (PCR) have been reported as a suitable tool for the rapid detection of these pathogens [9].

The present study was undertaken to: (1) Establish a simple PCR method that could identify strains of V. alginolyticus and V. parahaemolyticus isolated from infected sea bass (Dicentrarchus labrax); (2) characterize the virulence properties of isolates, such as cell surface hydrophobicity, capsule production, biofilm formation, adherence and invasion ability, and cytotoxicity, and (3) determine the relation between these different mechanisms.

\section{Material and Methods}

\subsection{Molecular Identification of V. parahaemolyticus and V. alginolyticus}

Thiosulfate citrate bile salts sucrose (TCBS) was used to isolate pathogenic bacteria belonging to the genus Vibrio from diseased sea bass fish (Dicentrarchus labrax) exhibiting enlarged spleens. After $24 \mathrm{~h}$ of incubation at $30{ }^{\circ} \mathrm{C}$, bacterial cultures giving pure green and yellow colonies were randomly selected then subcultured on tryptic soy agar (TSA, Difco, Spain) supplemented with $1 \%$ $\mathrm{NaCl}$ [21]. Heat-shock technique was used to extract DNA [22]. Collagenase-based multiplex PCR was performed to identify $V$. alginolyticus and $V$. parahaemolyticus from the presumptive isolates. In this study, primer pairs were used: VA-F $5^{\prime}$-cga gta cag tca ctt gaa agcc-3' $(1526-1547)$ and VA-R $5^{\prime}$-cac aac aga act cgc gtt acc-3' (2242-2263) for V. alginolyticus, producing a 737-bp long fragment; and for $V$. parahaemolyticus, VP-F 5'-gaa agt tga aca tca tca gca cga-3' (93-116) and VP-R 5'-ggt cag aat caa acg ccg-3' (347-364), which amplify a 271-bp region [9]. PCRs were carried out in a $25 \mu \mathrm{L}$ reaction mixture volume containing: $5 \mu \mathrm{L}$ of $5 \times$ PCR buffer, $0.25 \mu \mathrm{L}$ of $10 \mathrm{mM}$ dNTP's, $1 \mu \mathrm{L}$ of $25 \mathrm{pM}$ of each forward and reverse primers, $1 \mathrm{U}$ of Taq DNA polymerase (Promega, France), and 20 ng of extracted DNA. Distilled water was used to adjust reaction volume to $25 \mu \mathrm{L}$. Initial denaturation at $96^{\circ} \mathrm{C}$ for $4 \mathrm{~min}$, followed by 30 cycles of denaturation at $95^{\circ} \mathrm{C}$ for $30 \mathrm{~s}$, followed annealing at $66^{\circ} \mathrm{C}$ for $20 \mathrm{~s}$, then extension at $72{ }^{\circ} \mathrm{C}$ for $30 \mathrm{~s}$, and final extension $72{ }^{\circ} \mathrm{C}$ for $30 \mathrm{~s}$. 


\subsection{Hydrophobicity Analysis}

Bacterial adherence to hydrocarbons (BATH) test was used to assess the bacterial hydrophobicity. The BATH test was performed by measuring the cellular affinity for organic solvents. Strains were grown in TSB broth at $37^{\circ} \mathrm{C}$ for $18 \mathrm{~h}$. After being centrifugation at $5000 \mathrm{rpm}$ for $15 \mathrm{~min}$, the pellets were washed twice with phosphate buffer solution ( $\mathrm{pH} 7.2$ ). The density of cells was adjusted to 0.5 at $600 \mathrm{~nm}(\mathrm{~A} 0)$ and $4 \mathrm{~mL}$ of cell suspension was transferred to individual glass tubes, which contained $1 \mathrm{~mL}$ of n-Octane (Sigma ${ }^{\mathrm{TM}}$, St. Louis, MO, USA). The mixture was vigorously vortexed for $1 \mathrm{~min}$ and allowed at room temperature for $30 \mathrm{~min}$ to separate by decantation into two phases. The supernatant was removed and the absorbance was assessed at $600 \mathrm{~nm}$ (A1). The percentage of hydrophobicity was estimated according to the Equation (1):

$$
\text { Hydrophobicity }(\mathrm{H}) \%=(\mathrm{A} 0-\mathrm{A} 1) / \mathrm{A} 0 \times 100
$$

and strains are classified into three categories: Not hydrophobic $(<20 \%)$, Moderate $(20 \%-50 \%)$, and strong $(>50 \%)$.

\subsection{Detection of Capsule Production}

The evaluation of capsule production was assessed by culturing the Vibrio strains on Congo red agar (CRA) as described by Freeman et al. [16] with minor modifications. The CRA was prepared by mixing $36 \mathrm{~g}$ saccharose (Sigma Chemical Company, Lezennes, France) with $0.8 \mathrm{~g}$ Congo Red in $1 \mathrm{~L}$ of on Tryptic Soy Agar (TSA, Difco, City, Spain) supplemented with $\mathrm{NaCl}(1.0 \%)$. The inoculated plates were incubated aerobically for $24 \mathrm{~h}$ followed by $24 \mathrm{~h}$ at $30^{\circ} \mathrm{C}$. After incubation, black colonies were considered as capsule producers, whereas red colonies were non-producers [23].

\subsection{Adherence Assay}

Bacteria were grown in TSB at $30^{\circ} \mathrm{C}$ overnight and diluted to 1:100 $w / v$ (in TSB with $2 \%$ glucose). Aliquots of $200 \mu \mathrm{L}$ of the cell suspensions were transferred to U-bottomed 96-well microtiter plates (Nunc, Thermo Scientific ${ }^{\mathrm{TM}}$, Roskilde, Denmark). The microtitre plates were incubated for $24 \mathrm{~h}$ at $30{ }^{\circ} \mathrm{C}$, than washed twice with PBS and dried in inverted position. Wells with sterile TSB alone were used as controls. Adherent bacteria were fixed with ethanol (95\%) and stained with $100 \mu \mathrm{L}$ crystal violet $(1 \% w / v)$ solution for $5 \mathrm{~min}$. The microplates were washed and air-dried, and the optical density of each well was measured at $570 \mathrm{~nm}$ (OD570) using an automated Multiskan reader (Gio de Vita E C., Rome, Italy). Each strain was tested in triplicate.

Biofilm formation was interpreted as follows: Highly positive (OD570 $\geq 1)$, moderately to weakly positive $(0.1 \leq$ OD570 $<1)$, or negative (OD570 $\leq 0.1)$ [24].

\subsection{Determination of Cell Adherence and Invasion}

The Human epidermoid carcinoma epithelial cells (Hep-2; ATCC CCL-23) were cultured in RPMI 1640 (Biowest, Nuaillé, France) supplemented with 10\% fetal bovine serum (Biowest, Nuaillé, France), and antibiotics ( $2 \%$ penicillin-streptomycin $(100 \mathrm{IU} / \mathrm{mL})$, and $0.5 \%$ fungizone (Biowest) at $37{ }^{\circ} \mathrm{C}$ in a $5 \% \mathrm{CO}_{2}$ incubator. Every two days, the culture medium was changed and the Hep-2 cells were sub-cultured at $80 \%$ confluence [25]. Each bacterial inoculum consist of $\sim 10^{5}$ cells.

Each Vibrio strain was grown overnight in Tryptic Soy Broth (TSB, $1 \% \mathrm{NaCl}$ ) at $37^{\circ} \mathrm{C}$ with shaking (150 rpm). The bacterial cells were harvested by centrifugation at $4500 \mathrm{~g}$ for $15 \mathrm{~min}$, washed in PBS, and adjusted to an appropriate density in RPMI to give an M.O.I. of 100 (multiplicity of infection). Host cells were washed with RPMI and $1 \mathrm{~mL}$ of bacterial suspensions were added to wells and incubated for $2 \mathrm{~h}$ at $37^{\circ} \mathrm{C}$ in $5 \% \mathrm{CO}_{2}$. For quantitative adherence assays, Hep-2 cells were washed 3 times with RPMI to remove non-attached bacteria. The samples were then treated with lysis solution ( $0.1 \%$ Triton X100 (Merck KGaA, Darmstadt, Germany) in PBS) for 5 min at room temperature to detach the bacteria from the cells. By plating serial dilutions onto TSB agar plates $(1 \% \mathrm{NaCl})$ after 
aerobic incubation for $24 \mathrm{~h}$ at $37^{\circ} \mathrm{C}$, the total number of associated bacteria (adherent and internalized) was assessed

Gentamicin survival assay was used to quantify invasion and to obtain the number of intracellular bacteria. The same method described above was used, except that after $1 \mathrm{~h}$ incubation, the infected monolayer was treated with $100 \mu \mathrm{g} / \mathrm{mL}$ of the antibiotic (gentamicin solution) for $1 \mathrm{~h}$. This was carried to kill the extracellular bacteria. To remove gentamicin, the cells were washed with PBS three times. Host cells were then lysed and followed by serial dilution and spotting onto agar plates for bacterial cultured viable count. All experiments were carried out in triplicates.

Adherence was expressed as the percentage of cell-associated bacteria divided by the original inoculum $10^{7} \times 100$ (mean \pm the standard deviation) and invasion was expressed as the percentage of total adherent bacteria. The latter are the ones that resisted to the gentamicin killing divided by the number of inoculated bacteria $10^{7} \times 100$, as described previously [26].

\subsection{Cytotoxicity Assay}

The seven Vibrio species were inoculated in $15 \mathrm{~mL}$ sterile tubes containing TSB $(1 \% \mathrm{NaCl})$ and incubated for $18 \mathrm{~h}$ at $30^{\circ} \mathrm{C}$. Samples were adjusted to contain $10^{7} \mathrm{cfu} / \mathrm{mL}$ and after centrifugation at $3000 \mathrm{rpm}$ for $15 \mathrm{~min}$. a $0.22 \mu \mathrm{m}$ pore size filter membrane (Millipore, Darmstadt, Germany) was used to filter the supernatant. The MTT assay was carried out as described by [27]. Monolayers of Hep-2 cells cultivated in 96-well tissue culture plates were washed with PBS and $50 \mu \mathrm{L}$ aliquots of RPMI were added to each well. Fifty $\mu \mathrm{L}$ of bacterial filtrates for each strain were introduced into the wells of the test plates, and incubated at $37{ }^{\circ} \mathrm{C}$ in $5 \% \mathrm{CO}_{2}$ for $24 \mathrm{~h}$. Wells containing $50 \mu \mathrm{L}$ RPMI and $50 \mu \mathrm{L}$ sterile TSB served as controls. To kill the adherent bacteria, the cells were washed with PBS and incubated for $1 \mathrm{~h}$ with RPMI containing $300 \mu \mathrm{g} / \mathrm{mL}$ gentamicin. After washing with PBS, monolayers were exposed to 3-(4,5-Dimethylthiazol-2-yl)-2,5-diphenyltetrazolium bromide (MTT; Sigma, Darmstadt, Germany) at $5 \mathrm{mg} / \mathrm{mL}$ ( $50 \mu \mathrm{L} /$ well) in PBS for $3 \mathrm{~h}$ at $37^{\circ} \mathrm{C}$. Supernatants were then removed and cells were treated with $100 \mu \mathrm{L}$ absolute ethanol to dissolve the formazan crystals formed in the viable metabolically active cells. The absorbance was measured using microplate reader at $540 \mathrm{~nm}$ (GIO. DE VITA E C, Rome, Italy). The percentage cytotoxicity was calculated according to the Equation (2) [28]:

$$
\% \text { Cytotoxicity }=(1-(\text { A540 of infected culture } / \text { A540 of control })) \times 100
$$

Strains with cytotoxicity level lower than $50 \%$ were considered as weakly cytotoxic; from $50 \%$ to $85 \%$ as moderately cytotoxic; and those more than $85 \%$ as highly cytotoxic [29].

\subsection{Statistical Analysis}

Statistical analysis was out by using analysis of variance (ANOVA) and subsequently using Fisher PLSD multiple comparisons for the in vitro bacterial adhesion and invasion study. STATVIEW for Windows, version 5.4 (GE Healthcare, Milwaukee, WI, USA) was used. Spearman's correlation coefficient and their significance $(p)$ were investigated to correlate the differences between the different bacterial isolates in terms of the virulence properties (hydrophobicity; adhesion; invasion; biofilm; and cytotoxicity). The significance level for correlations was set to $p<0.05$ to indicate a statistically significant correlation. A correlation was considered strong as $r s$ approaches 1, intermediate if $r s$ was close to 0.5 , and weak if close to zero [30].

\section{Results}

\subsection{Molecular Identification of Isolates}

Among the twenty five bacterial strains isolated on Thiosulfate-Citrate-Bile-Sucrose (TCBS) agar plates, using a multiplex PCR, three strains were identified as V. alginolyticus (Va01, Va02, and Va03) 
giving an amplified fragment about $737 \mathrm{bp}$ and four strains as V. parahaemolyticus (Spa1, Spa2, Spa3, and Spa4) with a PCR product about 271 bp as shown in Figure 1.

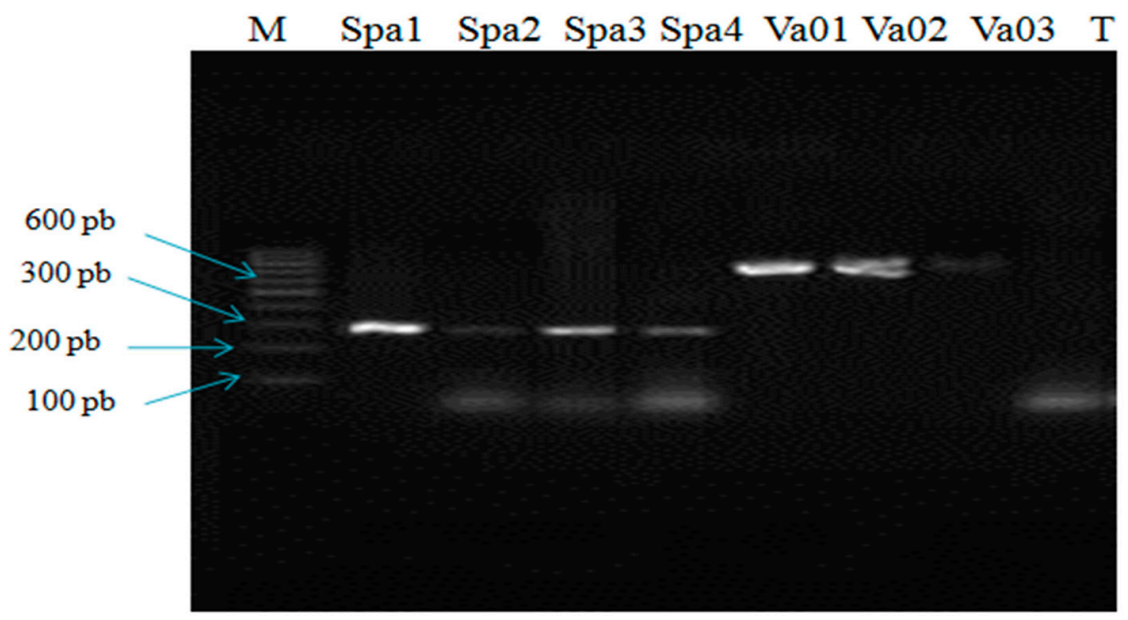

Figure 1. Agarose gel electrophoresis (1\% agarose) of the amplification products obtained for collagenase genes. (M): Molecular weight marker (100-pb DNA ladder, Invitrogen). Lane (Spa1; Spa2; Spa3; Spa4): V. parahaemolyticus. Lane (Va01; Va02; Va03): V. alginolyticus. Lane (T): Negative control.

\subsection{Hydrophobicity}

In this study, the cell surface hydrophobicity of the 7 Vibrio strains was characterized by using the BATH assay. The test was performed to analyze microbial linkage to n-octane and to estimate cell surface wettability. The results presented in Table 1 showed that three V. parahaemolyticus (Spa1: $60.8 \pm 2.8$; Spa2: $88.2 \pm 0.0$; Spa3: $87.3 \pm 1.4$ ) and one V. alginolyticus (Va01: $74.5 \pm 0.0$ ) were highly hydrophobic, whereas the other Vibrio strains (Spa4: $38.2 \pm 1.4$ ); (Va02: $32.4 \pm 1.4$ ), and (Va03: $39.2 \pm 2.8$ ) were found to be moderately hydrophobic.

Table 1. Capsule production and quantitative estimation of adhesion of Vibrio isolates to n-octane and abiotic materials (polystyrene).

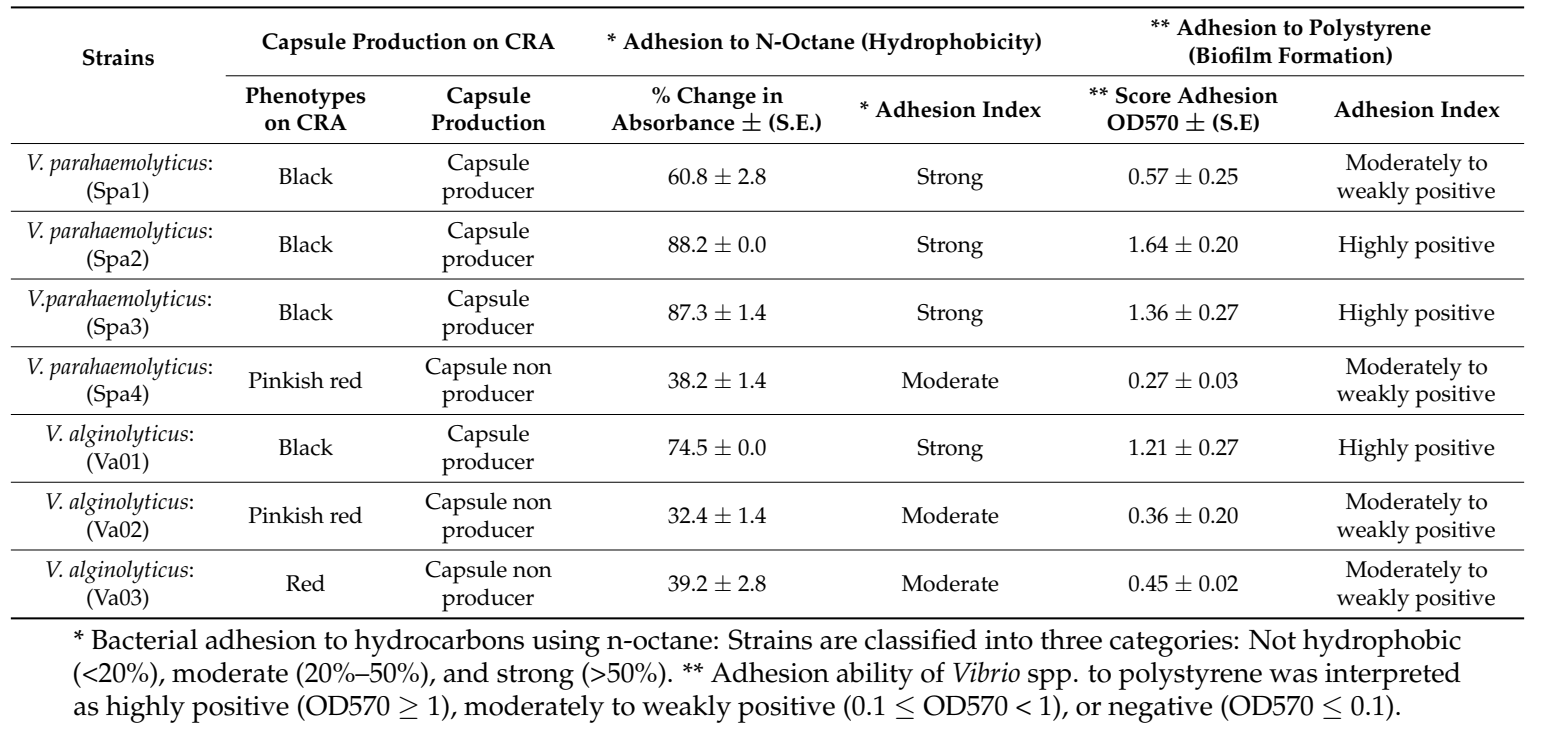

\subsection{Capsule Production and Biofilm Formation on Polystyrene Plates}

CRA method was used to evaluate the capability of Vibrio isolates in producing capsule as a presumptive test for biofilm production. Three V. parahaemolyticus (Spa1, Spa2, and Spa3) and only 
one V. alginolyticus (Va01) were showed to be capsule producer on CRA plates characterized by black colonies. The other remaining strains did not show capsule production and were characterized by forming red colonies (Table 1).

For biofilm formation, adherence assay to polystyrene plates revealed that two V. parahaemolyticus $\left(\left(\mathrm{Spa} 2\left(\mathrm{OD}_{570}=1.64 \pm 0.20\right)\right.\right.$ and Spa3 $\left.\left(\mathrm{OD}_{570}=1.36 \pm 0.27\right)\right)$ and one V. alginolyticus (Va01 $\left.\left(\mathrm{OD}_{570}=1.21 \pm 0.27\right)\right)$ were highly adherent to polystyrene plate. The remaining four isolates (Spa1, Spa4, Va02, and Va03) were moderately to weakly biofilm producers $(0.1 \leq$ OD570 $<1)$.

\subsection{Adhesion and Invasion to Human Epithelial Cells}

The ability of V.parahaemolyticus and V.alginolyticus strains to adhere to and invade Hep2 cells was presented in Figure 2 (adhesion) and Figure 3 (invasion). Results of adhesion were expressed as a percentage of the initial bacterial count, and have variable adherence levels $(4 \%-18 \%)$. V. alginolyticus (Va01) showed a high level of adhesion (18.98\%) to epithelial cell line and was significantly greater $(p<0.05)$ compared with the six other strains. It is followed by two V. parahaemolyticus Spa2 and Spa3 with adherence levels $16.59 \%$ and $15.13 \%$ respectively. The lowest adhesion ability was observed with V. alginolyticus Va03 with 4.53 of the added bacteria adhering to Hep-2 cell cultures. However, the adhesion level of Va03 strain did not significantly differ from the adhesion level of Va02 (4.58\%) and Sp4 (5.71\%).

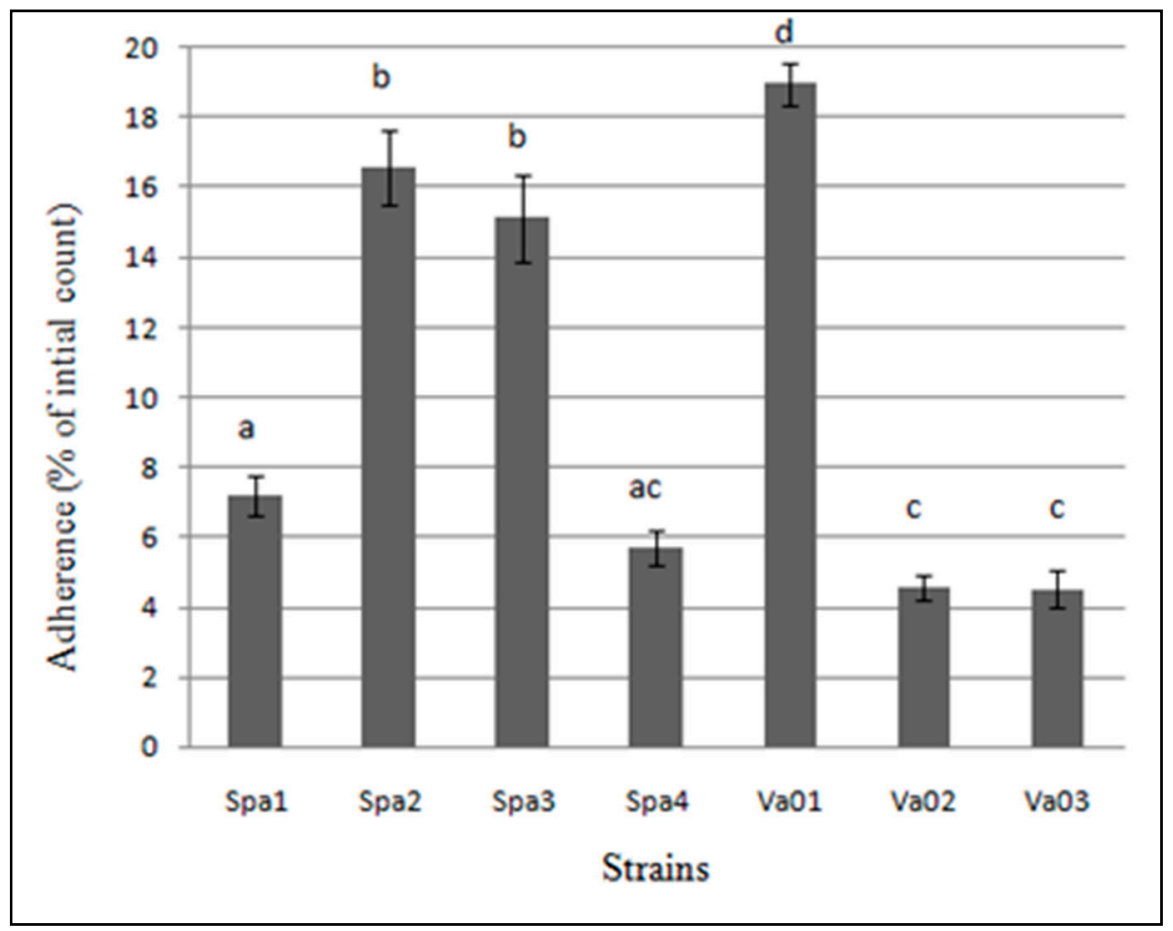

Figure 2. Percentage of adhesion of Vibrio parahaemolyticus and Vibrio alginolyticus strains to Hep-2 cells. The reported values are the means \pm SD of three independent experiments. Column bars with same letters indicate no significant difference $(p>0.05)$. 


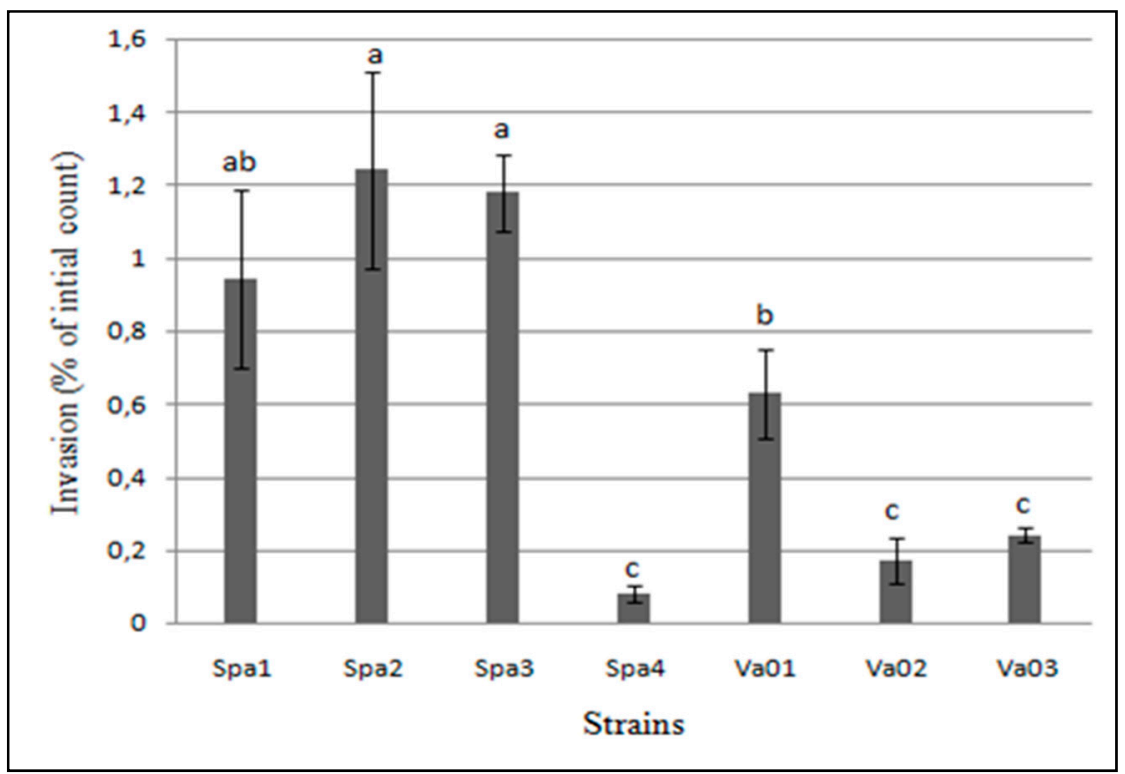

Figure 3. Percentage of invasion of Vibrio parahaemolyticus and Vibrio alginolyticus strains to Hep-2 cells. The reported values are the means \pm SD of three independent experiments. Column bars with same letters indicate no significant difference $(p>0.05)$.

The levels of cell invasion were not similar to the adhesion capability observed for each strain. The highest invasion level (1.24\%) was detected for V. parahaemolyticus Spa2 and differ significantly $(p<0.05)$ from that detected for V. parahaemolyticus Spa4 $(0.08 \%)$ and three V. alginolyticus Va01 $(0.63 \%)$, $\mathrm{Va} 02(0.17 \%)$, and $\mathrm{Va} 03(0.24 \%)$ representing the lowest level (Figure 3$)$.

\subsection{Cytotoxicity of the Bacterial Isolates to Hep-2 Cells}

The cytotoxicity of the seven Vibrio isolates was investigated. Results were expressed as \% cytotoxicity as showed in Figures 4 and 5 and Table 2. Although they showed different levels, all the tested isolates presented cytotoxicity towards Hep-2 cells after $24 \mathrm{~h}$ of infection. Four isolates (Spa1, Spa2, Spa3, and Va01) showed a moderate cytotoxicity potential (50\%-85\%). However, two V. alginolyticus (Va02 and Va03) and one V. parahaemolyticus Spa4 showed a low cytotoxicity $(<50 \%)$. A significant difference $(p<0.05)$ was found between moderate and low cytotoxic strains. 


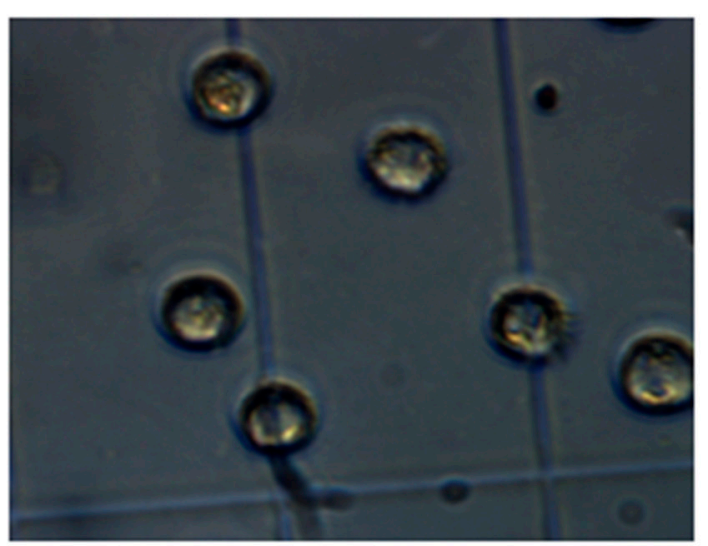

A

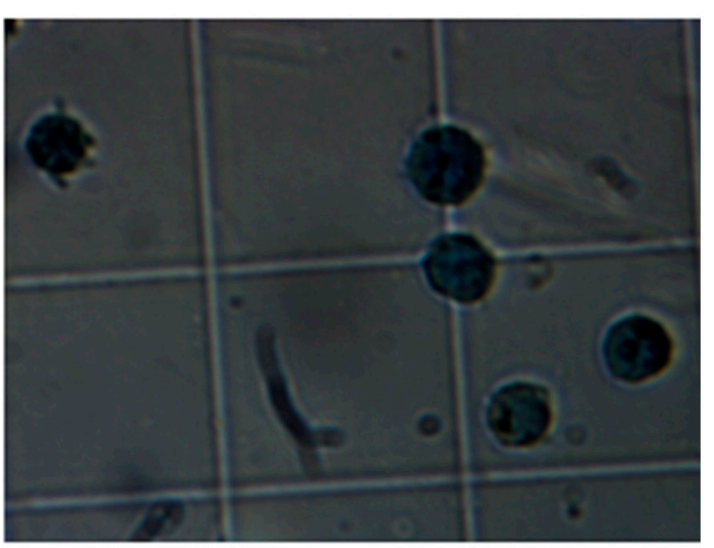

B

Figure 4. Light microscopy images showing the cytotoxic effect of Vibrio strains on Hep-2 cells, magnification (X100). (A) Control live unstained Hep-2 cells with an intact membrane and (B) dead (blue) stained Hep-2 cells infected with V. parahaemolyticus isolate (Spa1) for $24 \mathrm{~h}$.

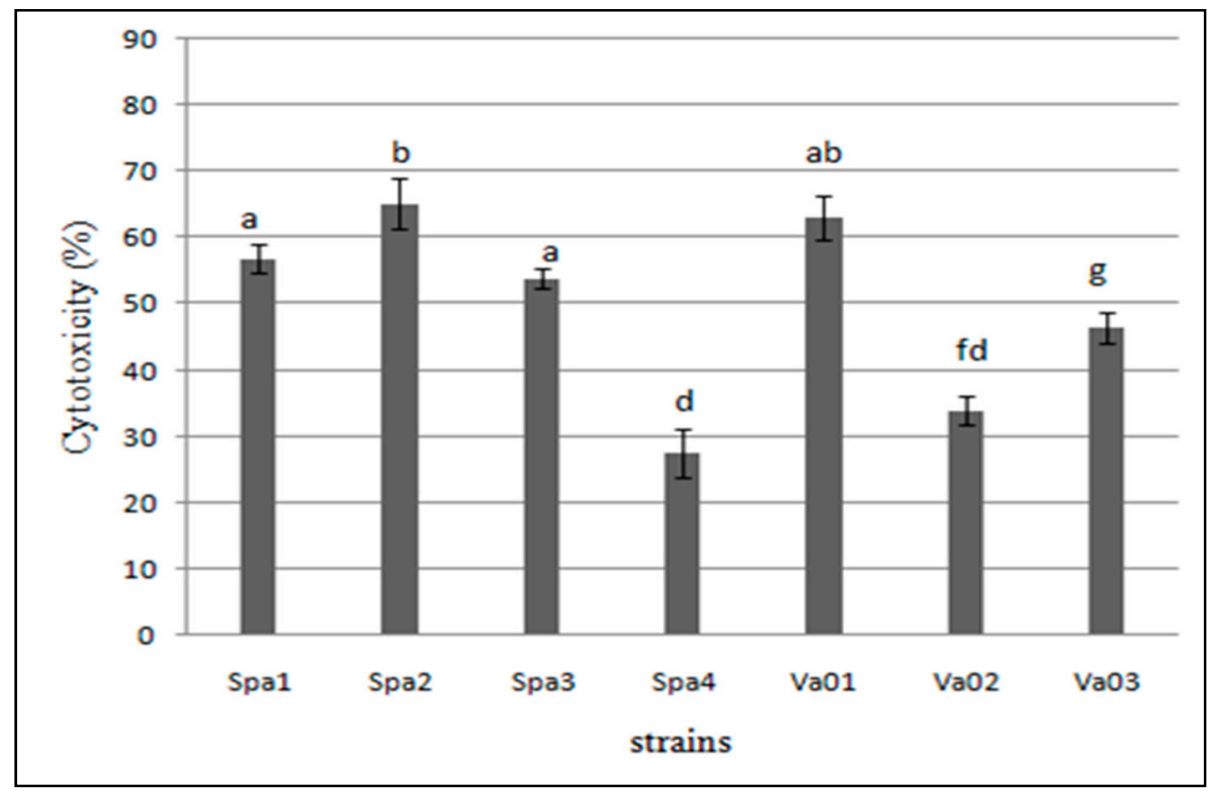

Figure 5. Cytotoxicity of cell-free supernatants and bacterial cells of the Vibrio parahaemolyticus and Vibrio alginolyticus isolates. The histograms represent the average percent cytotoxicity caused by the isolates and the error bars indicate the standard deviations of three independent experiments.

Table 2. Cytotoxicity of bacterial isolates to Hep-2 cells.

\begin{tabular}{ccccc}
\hline \multirow{2}{*}{ Bacterial Isolates } & \multicolumn{4}{c}{ Cytotoxicity Level of Bacterial Isolates } \\
\cline { 2 - 5 } & No Cytotoxicity & Low ${ }^{* *}$ & Moderate $^{* *}$ & High $^{* *}$ \\
\hline \multirow{3}{*}{ V. parahaemolyticus } & - & Sp4 & Spa1 & - \\
& - & - & Spa2 & - \\
\hline \multirow{2}{*}{ V. alginolyticus } & - & - & Spa3 & - \\
\hline & - & Va02 & Va01 & - \\
\hline
\end{tabular}

** Low cytotoxicity $(<50 \%)$, moderate (50 to $85 \%)$ and high $(>85 \%)$. 


\subsection{Relationship between Hydrophobicity, Biofilm, Adherence, Invasion and Cytotoxicity of the Vibrio Strains}

In order to determine whether a relation existed between these different virulence properties (hydrophobicity, biofilm, adherence, invasion, and cytotoxicity), the results were analyzed using Spearman's correlation coefficient as shown in Table 3. It is readily seen from Table 3 that a strong and significant $(p<0.05)$ positive correlation was obtained between: (i) Hydrophobicity and biofilm production on polysterene plates ( $r s=0.89$ ); (ii) biofilm formation and adherence to epithelial cells ( $r s=0.92)$; (iii) adherence and invasion to Hep-2 cells ( $r s=0.70)$; (iv) adherence to epithelial cells and cytotoxicity ( $r s=0.80)$; and $(\mathrm{v})$ between invasion and cytotoxicity $(r s=0.86)$.

Table 3. Spearman's correlation coefficient values between different pairs of virulence properties of the different bacterial isolates.

\begin{tabular}{cccccc}
\hline & \multicolumn{5}{c}{ Virulence Properties } \\
\cline { 2 - 6 } Bacterial Isolates & $\begin{array}{c}\text { Hydrophobicity } \\
\text { Using N-Octane } \\
\text { vs. Adhesion to } \\
\text { Polystyrene Plates }\end{array}$ & $\begin{array}{c}\text { Adhesion to } \\
\text { Polystyrene Plates } \\
\text { vs. Adhesion to } \\
\text { Hep-2 Cells }\end{array}$ & $\begin{array}{c}\text { Adhesion vs. } \\
\text { Invasion } \\
\text { (to Hep-2 Cells) }\end{array}$ & $\begin{array}{c}\text { Adhesion vs. } \\
\text { Cytotoxicity } \\
\text { (to Hep-2 Cells) }\end{array}$ & $\begin{array}{c}\text { Invasion vs. } \\
\text { Cytotoxicity } \\
\text { (to Hep-2 Cells) }\end{array}$ \\
\hline Vibrio species & $+0.89^{*}$ & $+0.92^{*}$ & $+0.70^{*}$ & $+0.80^{*}$ & $+0.86^{*}$ \\
\hline \multicolumn{7}{c}{ Significance level: ${ }^{*} p<0.05}$.
\end{tabular}

\section{Discussion}

V. parahaemolyticus and V. alginolyticus strains were halophilic bacteria that commonly inhabit the marine and estuarine environments and were characterized as important pathogens in aquaculture farms [2,31]. It was previously reported that Vibrio alginolyticus and Vibrio parahaemolyticus have major virulence genes (e.g., the collagenase gene) leading to the high virulence of the pathogens [9]. Miyoshi et al. (2008) studied the collagenases of Vibrio parahaemolyticus as virulence causes for invasiveness and tissue injury [10]. In addition, this virulence gene was commonly found in green mussels [32]. The multiplex PCR procedures using two simultaneous primers targeting V. alginolyticus, and V. parahaemolyticus collagenase gene allowed successful detection of the two Vibrio species. As shown in Figure 1, seven Vibrio strains were isolated from diseased Dicentrarchus labrax and identified within biochemical method as V. alginolyticus (Va01, Va02, and Va03) and V. parahaemolyticus (Spa1, Spa2, Spa3, and Spa4). We showed in this study that the collagenase gene might be a useful alternative target for species identification of vibrios. The selected oligonucleotide primers from the collagenase were highly specific for their respective target gene segments [9]. It is worth mentioning at this level that it has been shown that thiosulfate citrate bile agar (TCBS) is more selective than thiosulphate-chloride-iodide (TCI). The latter is routinely used in clinical settings for isolation of vibrio subspecies, however, some other pathogens can grow [33]. Other sophisticated techniques can give results with less contamination risks [34].

To become a pathogen, vibrios have to gain access to the animal host usually by adhering to biotic surfaces. Components of the extracellular matrix are involved in this adhesion to the host tissue. For the abiotic surfaces, materials such as polystyrene, polyethylene, and silicon used in aquaculture installations will serve as support materials for vibrios. Following bacterial adhesion on the respective surface (biotic or abiotic), biofilms arise [35]. In order to launch infection, pathogens must be capable of evading the host antimicrobial agents. Bacteria need different virulence properties, like hydrophobicity, adhesion and invasion ability, and biofilm formation. During infection, these virulence factors are crucial for the bacteria $[12,36]$. For that reason, an extensive characterization of important virulence factors and their relationship was carried out.

It was reported that hydrophobicity and biofilm formation are important features of the adhesion and the survival of pathogens in cells. Our study demonstrated that four strains (Spa1, Spa2, Spa3, and Va01) showed strong hydrophobicity due to their ability to absorb to n-octane according to the BATH test (Table 1). A higher percentage of hydrophobicity was observed for V. harveyi using 
n-octane as a solvent in BATH assay, whereas low hydrophobicity has been found in $V$. fischeri, $V$. nereis, $V$. harveyi, and $V$. anguillarum. It has been shown that surface hydrophobicity facilitates the bacterial contact and leads to increased bacterial adherence. Indeed, we observed that the high hydrophobic strains presented an enhanced adherence and biofilm production on polystyrene plates. In general, it is assumed that plastics are hydrophobic materials [37]. In previous studies, it has been reported that micro-organisms attach rapidly to hydrophobic surfaces that have not polar functional groups (such as glass or metals) than hydrophilic surfaces $[38,39]$. Thus, hydrophobic interactions favor the adhesion and colonization ability of a pathogen. Interestingly, statistical analysis revealed a statistically significant positive correlation between the hydrophobicity and biofilm production on polystyrene microtiter plates of the Vibrio species ( $\mathrm{rs}=0.89, p<0.05)$ (Table 3). As reported in previous studies [40], these findings put forward the importance of hydrophobicity in bacterial interactions with biotic or abiotic surfaces. Niderman-Meyer et al. [41] reported on the ability of Vibrio cholerae to adhere to cornstarch granules, showing specific and nonspecific interactions. Although both (cornstarch granules and V. cholera) exhibit hydrophobic properties, the adhesion was possible involving some specific carbohydrate-binding moieties on the cell surface. Pretreatment of the bacteria with sodium m-periodate and proteinase $\mathrm{K}$ did not inhibit this adhesion, however, low-molecular-weight carbohydrates inhibited it. The same authors showed the contribution of some proteins to the adhesion of vibrio to cornstarch granules surface. These surface proteins may change from one vibrio-specie to another and consequently different adhesion tendencies to a given surface can be observed. Moreover, the adhesion of vibrios to biotic and/or abiotic surfaces can be influenced by the roughness of the surface itself. This parameter is out of the scope of the actual study.

Using the CRA plate method, the four isolates appeared as black colonies on the red agar (Table 1) indicate the ability of these strains to produce capsule and biofilm. In agreement with previous reports, capsule production by microorganism plays an important role in biofilm formation [42]. Therefore, the capsule expression mechanism had significant effects on some bacterial mechanisms, like biofilm formation. In this study, the assays performed with the CRA plate method showed the mechanism behind the adhesion of Vibrio strains on abiotic surfaces (microtiter polystyrene plate). These mechanisms are in agreement with observations reported by [16,43]. The latter studies showed that capsule production by Staphylococcus strains facilitates bacterial adhesion to a substrate through its biopolymer components leading to the formation of the biofilm. Based on our results we are able to recommend the CRA method used typically for the detection of biofilm formation by Vibrio isolates. The adhesion capacity to biotic and abiotic surfaces has been regarded as one of the most important criteria to select pathogen strains, thus the CRA plate method, BATH, and polystyrene microtiter plates tests are useful tools for such a purpose.

After screening of the seven isolates for capsule production, hydrophobicity, and adhesion to polystyrene, it was worth investigating a possible relationship between these different virulence properties and the ability of the tested isolates to interact with Hep-2 cells. Using the measured adhesion level of isolates to Hep-2, the present study revealed the ability of all the tested isolates to adhere to the Hep-2 cell line, but by variable degrees (Figure 2). Interestingly, strains Va01, Spa1, Spa2, and Spa3 showed a high level of adhesion. As described above, the adhesion ability to Hep-2 cells appeared to be increased with capsule production, hydrophobicity, and adhesion to polystyrene. In addition, the statistical analysis, using Spearman's correlation coefficient, of biofilm formation on polystyrene plates and adhesion to Hep-2 cells of all the tested isolates revealed a strong and significant positive correlation $(r s=+0.92, p<0.05)$ (Table 3). Our findings indicate that higher adherence of these four Vibrio isolates to epithelial cell lines may be due to hydrophobic interactions and capsular formation $[37,44]$. It has been postulated that the E. coli capsule may promote adherence $[45,46]$. Moreover, the capsule of $V$. cholerae $\mathrm{O} 139$ is related to effective adherence to the human intestinal mucosa. On the other hand, it has been found that a capsule may reduce adhesiveness in Actinobacillus pleuropneumoniae [47] and Pasteurella multocida [48]. Other components like fimbria, flagellum, alginate, and LPS produced by bacteria can also ease adhesion and biofilm formation [49]. 
In case of invasion properties, as shown in Figures 2 and 3, results revealed that three V. parahaemolyticus (Spa2, Spa3, Spa1) and one V. alginolyticus (Va01) showed higher invasion percentage and adherence too. Among these isolates, strain Spa1 represented a fewer adherent and invasion degrees. As indicated in Table 1, strains which produce capsule, were highly invasive in Hep-2 cells. A capsule of $P$. gingivalis W83 was highly invasive in human coronary artery endothelial cells (HCAEC). However, both capsulated and non-capsulated strains of $P$. damselae appear to be able to invade fish epithelial cells. In this study, the presence of a capsule appears to be a major factor of invasiveness. As presented in Table 3, all isolates showed a strong and positive significant correlation between the adherence and the invasion to Hep-2 cells $(r s=0.70, p<0.05)$. Our results demonstrate that invasion step is anterior to the adherence action. Also, we showed that adherence to the host cells is the first step leading to invasion, which is in agreement with results previously reported [29].

Tissue cultures have recently been used to investigate the cytotoxic activities of Aeromonas spp. strains [50]. The Vibrio strains were previously characterized by cytotoxic activities. It has been described that the extracellular products of Vibrio harveyi CAIM 1792 strain, isolated from infected shrimp, L. vannamei, exhibited a strong cytotoxic activity to HELA cell line after 6 and $24 \mathrm{~h}$ inoculation [51]. In addition, it was reported that $10^{-4}$ dilutions of the culture filtrate of Vibrio cholerae, Vibrio parahemolyticus, and Vibrio vulnificus showed greater toxic potential to Vero cells [52]. In the present study, cytotoxicity of Vibrio isolates was investigated using the MTT assay. After $24 \mathrm{~h}$ of incubation with Hep-2 cells, results revealed the presence of four isolates (Spa1, Spa2, Spa3, and Va01) shown a moderate cytotoxicity potential $(50 \%-85 \%)$ and a significant difference compared to the other three strains (Spa4, Va02, and Va03), which exhibited a low cytotoxicity $(<50 \%)$. A recent study reported the cytotoxicity was related to the presence of capsule, also it has been described that capsule of $V$. vulnificus strains correlated with bacterial virulence and enables these strains to avoid host immune cells [53]. In our study, the presence of capsule was related to the cytotoxicity of isolates. In this fact, we found that the four strains which exhibited moderate cytotoxicity level are capsule producer. Some reports indicated that there is a relationships adherence, invasion, and cytotoxicity. For example, studies with Vero cells demonstrated a strong correlation between the adherence and cytotoxicity of the Staphylococcus and Pseudomonas species and between invasion and cytotoxicity in case of Pseudomonas isolates only [29]. This is in good agreement with our findings, as we observed a strong correlation between the adhesion to Hep-2 cells and the cytotoxicity ( $r s=0.80, p<0.05)$, as well as invasion and cytotoxicity ( $r s=0.86, p<0.05)$. However, these results are not in agreement with those previously reported by [54]. The latter study showed a weak non-significant negative correlation with Klebsiella pneumoniae strains for the cytotoxicity and adherence and the invasion and cytotoxicity [55].

In a relatively small volume of water, sea bass farming can get infected causing morbidity and mortality. Vibrios are major bacterial pathogens for aquaculture fish. Bacterial contact with biotic surfaces as well as adhesion and invasion are essential steps to induce cytotoxicity. This study is a step forward helping to understand and to prevent infections and biofilm formation in aquaculture. This is an important topic in the context of food safety [56].

\section{Conclusions}

In conclusion, we isolated seven Vibrio strains from diseased sea bass fish, which possessed a collagenase gene and may produce metalloproteases, causing degradation of conjunctive tissue, which leads to high mortality rates and major production losses in fish farms. These isolates were evaluated for their virulence properties. They showed moderate to high cell surface hydrophobicity and biofilm production. A strong and statistically significant positive correlation was observed between these virulence properties. Biofilm formation may induce colonization of pathogens bacteria of various aquaculture installations, with risks to aquatic animal farming. Capsule formation, detected by CRA, may modulate this process.

Vibrio strains were also able to adhere and invade Hep-2 cells by variable degrees and they showed different levels of cytotoxicity in epithelial cells. A strong and significant positive correlation 
was observed between the adhesion and the invasion to Hep-2 cells. This indicates that invasion is a post-adherence event. The level of adhesion and invasion was also highly correlated to the cytotoxicity of Vibrio strains. This finding indicated that adhesion and invasion were required for induction of cytotoxicity. Future investigation using up-to-date microscopy techniques (e.g., confocal microscopy, SEM) and/or others techniques for adhesion and biofilm formation may help to better understand this bio-interface.

Author Contributions: Conceptualization, S.R.; Data curation, F.L. and S.K.; Formal analysis, F.L.; Supervision, S.R.

Funding: This research received no external funding.

Conflicts of Interest: The authors declare no conflict of interest.

\section{References}

1. Bondad-Reantaso, M.G.; Subasinghe, R.P.; Arthur, J.R.; Ogawa, K.; Chinabut, S.; Adlard, R.; Tan, Z.; Shariff, M. Disease and health management in Asian aquaculture. Vet. Parasitol. 2005, 132, 249-272. [CrossRef] [PubMed]

2. Austin, B.; Austin, D.A. Bacterial Fish Pathogens, Disease of Farmed and Wild Fish; Springer Praxis: Godalming, UK, 2007.

3. Ben Kahla-Nakbi, A.; Besbes, A.; Chaieb, K.; Rouabhia, M.; Bakhrouf, A. Survival of Vibrio alginolyticus in seawater and retention of virulence of its starved cells. Mar. Environ. Res. 2007, 64, 469-478. [CrossRef] [PubMed]

4. Torrecillas, S.; Makol, A.; Caballero, M.J.; Montero, D.; Dhanasiri, A.K.S.; Sweetman, J.; Izquierdo, M. Effects on mortality and stress response in European sea bass, Dicentrarchus labrax (L.), fed mannan oligosaccharides (MOS) after Vibrio anguillarum exposure. J. Fish Dis. 2012, 35, 591-602. [CrossRef] [PubMed]

5. Zavala-Norzagaray, A.A.; Aguirre, A.A.; Velazquez-Roman, J.; Flores-Villaseñor, H.; León-Sicairos, N.; Ley-Quiñonez, C.P.; Hernández-Díaz, L.D.J.; Canizalez-Roman, A. Isolation, characterization, and antibiotic resistance of Vibrio spp. in sea turtles from Northwestern Mexico. Front. Microbiol. 2015, 6. [CrossRef] [PubMed]

6. Reilly, G.; Reilly, C.; Smith, E.; Baker-Austin, C. Vibrio alginolyticus-associated wound infection acquired in British waters, Guernsey, July 2011. Euro Surveill. 2011, 16, 10.

7. Velazquez-Roman, J.; León-Sicairos, N.; de Jesus Hernández-Díaz, L.; Canizalez-Roman, A. Pandemic Vibrio parahaemolyticus O3: K6 on the American continent. Front. Cell Infect. Microbiol. 2013, 3, 110. [CrossRef] [PubMed]

8. Secades, P.; Guijarro, J.A. Purification and characterization of an extracellular protease from the fish pathogen Yersinia ruckeri and effect of culture conditions on production. Appl. Environ. Microbiol. 1999, 65, 3969-3975. [PubMed]

9. Di Pinto, A.; Ciccarese, G.; Tantillo, G.; Catalano, D.; Forte, V.T. A collagenase-targeted multiplex PCR assay for identification of Vibrio alginolyticus, Vibrio cholerae, and Vibrio parahaemolyticus. J. Food Prot. 2005, 68, 150-153. [CrossRef] [PubMed]

10. Miyoshi, S.-I.; Nitanda, Y.; Fujii, K.; Kawahara, K.; Li, T.; Maehara, Y.; Ramamurthy, T.; Takeda, Y.; Shinoda, S. Differential gene expression and extracellular secretion of the collagenolytic enzymes by the pathogen Vibrio parahaemolyticus. FEMS Microbiol. Lett. 2008, 283, 176-181. [CrossRef]

11. Pizarro-Cerdá, J.; Cossart, P. Bacterial adhesion and entry into host cells. Cell 2006, 124, 715-727. [CrossRef]

12. Silva-Dias, A.; Miranda, I.M.; Branco, J.; Monteiro-Soares, M.; Pina-Vaz, C.; Rodrigues, A.G. Adhesion, biofilm formation, cell surface hydrophobicity, and antifungal planktonic susceptibility: Relationship among Candida spp. Front. Microbiol. 2015, 6. [CrossRef] [PubMed]

13. Gulig, P.A.; Bourdage, K.L.; Starks, A.M. Molecular pathogenesis of Vibrio vulnificus. J. Microbiol. 2005, 43, 118-131. [PubMed]

14. Nakano, V.; Piazza, R.; Cianciarullo, A.; Bueris, V.; Santos, M.; Menezes, M.; Mendes-Ledesma, M.; Szulczewski, V.; Elias, W.; Pumbwe, L. Adherence and invasion of Bacteroidales isolated from the human intestinal tract. Clin. Microbiol. Infect. 2008, 14, 955-963. [CrossRef]

15. Beena, V.; Shivananda, P. In vitro adhesiveness of Bacteroides fragilis group in relation to encapsulation. Indian J. Med. Res. 1997, 105, 258-261. [PubMed] 
16. Freeman, D.; Falkiner, F.; Keane, C. New method for detecting slime production by coagulase negative staphylococci. J. Clin. Pathol. 1989, 42, 872-874. [CrossRef] [PubMed]

17. Chmielewski, R.; Frank, J. Biofilm formation and control in food processing facilities. Comprehensive reviews in food science and food safety. Compr. Rev. 2003, 2, 22-32.

18. Cantet, F.; Hervio-Heath, D.; Caro, A.; Le Mennec, C.; Monteil, C.; Quemere, C.; Jolivet-Gougeon, A.; Colwell, R.R.; Monfort, P. Quantification of Vibrio parahaemolyticus, Vibrio vulnificus and Vibrio cholerae in French Mediterranean coastal lagoons. Res. Microbiol. 2013, 164, 867-874. [CrossRef]

19. Snoussi, M.; Noumi, E.; Cheriaa, J.; Usai, D.; Sechi, L.A.; Zanetti, S.; Bakhrouf, A. Adhesive properties of environmental Vibrio alginolyticus strains to biotic and abiotic surfaces. New Microbiol. 2008, 31, 489-500.

20. Fabbro, C.; Celussi, M.; Russell, H.; Del Negro, P. Phenotypic and genetic diversity of coexisting Listonella anguillarum, Vibrio harveyi and Vibrio chagassi recovered from skin haemorrhages of diseased sand smelt, Atherina boyeri, in the Gulf of Trieste (NE Adriatic Sea). Lett. Appl. Microbiol. 2012, 54, 153-159. [CrossRef]

21. Hara-Kudo, Y.; Nishina, T.; Nakagawa, H.; Konuma, H.; Hasegawa, J.; Kumagai, S. Improved method for detection of Vibrio parahaemolyticus in seafood. Appl. Environ. Microbiol. 2001, 67, 5819-5823. [CrossRef]

22. Chapman, P.; Ellin, M.; Ashton, R.; Shafique, W. Comparison of culture, PCR and immunoassays for detecting Escherichia coli $\mathrm{O} 157$ following enrichment culture and immunomagnetic separation performed on naturally contaminated raw meat products. Int. J. Food Microbiol. 2001, 68, 11-20. [CrossRef] 
23. Zaranza, A.V.; Morais, F.C.; do Carmo, M.S.; de Mendonça Marques, A.; Andrade-Monteiro, C.; Ferro, T.F.; Monteiro-Neto, V.; Figueiredo, P.d.M.S. Antimicrobial susceptibility, biofilm production and adhesion to HEp-2 cells of Pseudomonas aeruginosa strains isolated from clinical samples. J. Biomater. Nanobiotechnol. 2013, 4, 98-106. [CrossRef]

24. Chaieb, K.; Zmantar, T.; Souiden, Y.; Mahdouani, K.; Bakhrouf, A. XTT assay for evaluating the effect of alcohols, hydrogen peroxide and benzalkonium chloride on biofilm formation of Staphylococcus epidermidis. Microb. Pathog. 2011, 50, 1-5. [CrossRef] [PubMed]

25. Jensen, H.; Grimmer, S.; Naterstad, K.; Axelsson, L. In vitro testing of commercial and potential probiotic lactic acid bacteria. Int. J. Food Microbiol. 2012, 153, 216-222. [CrossRef] [PubMed]

26. Tang, P.; Foubister, V.; Pucciarelli, M.G.; Finlay, B.B. Methods to study bacterial invasion. J. Microbiol. Methods 1993, 18, 227-240. [CrossRef]

27. Saliba, A.M.; Filloux, A.; Ball, G.; Silva, A.S.; Assis, M.-C.; Plotkowski, M.-C. Type III secretion-mediated killing of endothelial cells by Pseudomonas aeruginosa. Microb. Pathog. 2002, 33, 153-166. [CrossRef]

28. Murakami, J.; Kishi, K.; Hirai, K.; Hiramatsu, K.; Yamasaki, T.; Nasu, M. Macrolides and clindamycin suppress the release of Shiga-like toxins from Escherichia coli O157: H7 in vitro. Int. J. Antimicrob. Agents 2000, 15, 103-109. [CrossRef]

29. El-Housseiny, G.S.; Aboulwafa, M.M.; Hassouna, N.A. Adherence, invasion and cytotoxicity of some bacterial pathogens. J. Am. Sci. 2010, 6, 260-268.

30. Da Silva, M.E.Z.; Camargo Filho, I.; Endo, E.H.; Nakamura, C.V.; Ueda-Nakamura, T.; Dias Filho, B.P. Characterisation of potential virulence markers in Pseudomonas aeruginosa isolated from drinking water. Antonie van Leeuwenhoek 2008, 93, 323-334. [CrossRef]

31. Hsern Malcolm, T.T.; Cheah, Y.K.; Radzi, C.W.J.W.M.; Kasim, F.A.; Kantilal, H.K.; Huat John, T.Y.; Martinez-Urtaza, J.; Nakaguchi, Y.; Nishibuchi, M.; Son, R. Detection and quantification of pathogenic Vibrio parahaemolyticus in shellfish by using multiplex PCR and loop-mediated isothermal amplification assay. Food Control 2015, 47, 664-671. [CrossRef]

32. Lafisca, A.; Pereira, C.S.; Giaccone, V.; Rodrigues, D.d.P. Enzymatic characterization of Vibrio alginolyticus strains isolated from bivalves harvested at Venice Lagoon (Italy) and Guanabara Bay (Brazil). Rev. Inst. Med. Trop. São Paulo 2008, 50, 199-202. [CrossRef] [PubMed]

33. Pfeffer, C.; Oliver, J.D. A comparison of thiosulphate-citrate-bile salts-sucrose (TCBS) agar and thiosulphate-chloride-iodide (TCI) agar for the isolation of Vibrio species from estuarine environments. Lett. Appl. Microbiol. 2003, 36, 150-151. [CrossRef]

34. Strand, M.; Hedström, M.; Seth, H.; McEvoy, E.G.; Jacobsson, E.; Göransson, U.; Andersson, H.S.; Sundberg, P. The Bacterial (Vibrio alginolyticus) Production of Tetrodotoxin in the Ribbon Worm Lineus longissimus -Just a False Positive? Mar. Drugs 2016, 14, 63. [CrossRef] [PubMed]

35. Linke, D.; Goldman, A. Bacterial Adhesion: Chemistry, Biology and Physics; Springer Science \& Business Media: Berlin, Germany, 2011; Volume 715.

36. Kauppi, A. Chemical Attenuation of Bacterial Virulence: Small Molecule Inhibitors of Type III Secretion. 2006. Available online: http:/ / www.diva-portal.org/smash/record.jsf?pid=diva2\%3A145112\&dswid=2468 (accessed on 1 June 2017).

37. Peters, G.; Pulverer, G. Pathogenesis and management of Staphylococcus epidermidis 'plastic' foreign body infections. J. Antimicrob. Chemother. 1984, 14, 67-71. [CrossRef] [PubMed]

38. Sinde, E.; Carballo, J. Attachment of Salmonella spp. and Listeria monocytogenes to stainless steel, rubber and polytetrafluorethylene: The influence of free energy and the effect of commercial sanitizers. Food Microbiol. 2000, 17, 439-447. [CrossRef]

39. Fletcher, M.; Loeb, G. Influence of substratum characteristics on the attachment of a marine pseudomonad to solid surfaces. Appl. Environ. Microbiol. 1979, 37, 67-72. [PubMed]

40. Bendinger, B.; Rijnaarts, H.H.; Altendorf, K.; Zehnder, A.J. Physicochemical cell surface and adhesive properties of coryneform bacteria related to the presence and chain length of mycolic acids. Appl. Environ. Microbiol. 1993, 59, 3973-3977.

41. Niderman-Meyer, O.; Zeidman, T.; Shimoni, E.; Kashi, Y. Mechanisms Involved in Governing Adherence of Vibrio cholerae to Granular Starch. Appl. Environ. Microbiol. 2010, 76, 1034-1043. [CrossRef] 
42. Van Loosdrecht, M.C.; Norde, W.; Zehnder, A. Physical chemical description of bacterial adhesion. J. Biomater. Appl. 1990, 5, 91-106. [CrossRef]

43. Jain, A.; Agarwal, A. Biofilm production, a marker of pathogenic potential of colonizing and commensal staphylococci. J. Microbiol. Methods 2009, 76, 88-92. [CrossRef]

44. Carbone, M.; Maugeri, T.L.; Giannone, M.; Gugliandolo, C.; Midiri, A.; Fera, M.T. Adherence of environmental Arcobacter butzleri and Vibrio spp. isolates to epithelial cells in vitro. Food Microbiol. 2003, 20, 611-616. [CrossRef]

45. Kabha, K.; Schmegner, J.; Keisari, Y.; Parolis, H.; Schlepper-Schaeffer, J.; Ofek, I. SP-A enhances phagocytosis of Klebsiella by interaction with capsular polysaccharides and alveolar macrophages. Am. J. Physiol.-Lung Cell. Mol. Physiol. 1997, 272, L344-L352. [CrossRef]

46. Davis, C.; Avots-Avotins, A.; Fader, R. Evidence for a bladder cell glycolipid receptor for Escherichia coli and the effect of neuraminic acid and colominic acid on adherence. Infect. Immunity 1981, 34, 944-948.

47. Chan, R.; Acres, S.; Costerton, J. Use of specific antibody to demonstrate glycocalyx, K99 pili, and the spatial relationships of $\mathrm{K} 99+$ enterotoxigenic Escherichia coli in the ileum of colostrum-fed calves. Infect. Immunity 1982, 37, 1170-1180.

48. Jacques, M.; Bélanger, M.; Roy, G.; Foiry, B. Adherence of Actinobacillus pleuropneumoniae to porcine tracheal epithelial cells and frozen lung sections. Vet. Microbiol. 1991, 27, 133-143. [CrossRef]

49. Jacques, M.; Kobisch, M.; Belanger, M.; Dugal, F. Virulence of capsulated and noncapsulated isolates of Pasteurella multocida and their adherence to porcine respiratory tract cells and mucus. Vet. Microbiol. 1993, 61, 4785-4792.

50. Vesterlund, S.; Paltta, J.; Karp, M.; Ouwehand, A.C. Measurement of bacterial adhesion-In vitro evaluation of different methods. J. Microbiol. Methods 2005, 60, 225-233. [CrossRef] [PubMed]

51. Dos Santos, P.A.; Pereira, A.C.M.; Ferreira, A.F.; de Mattos Alves, M.A.; Rosa, A.C.P.; Freitas-Almeida, A.C. Adhesion, invasion, intracellular survival and cytotoxic activity of strains of Aeromonas spp. in HEp-2, Caco-2 and T-84 cell lines. Antonie van Leeuwenhoek 2015, 107, 1225-1236. [CrossRef] [PubMed]

52. Soto-Rodriguez, S.A.; Gomez-Gil, B.; Lozano, R.; del Rio-Rodríguez, R.; Diéguez, A.L.; Romalde, J.L. Virulence of Vibrio harveyi responsible for the "Bright-red" Syndrome in the Pacific white shrimp Litopenaeus vannamei. J. Invertebr. Pathol. 2012, 109, 307-317. [CrossRef]

53. Moitra, S.; Seethalakshmi, I.; Jeyanthi Rebecca, L. Toxicity analysis of vibrio species from fish samples. J. Chem. Pharm. Res. 2013, 5, 128-130.

54. Jones, M.K.; Oliver, J.D. Vibrio vulnificus: Disease and Pathogenesis. Infect. Immun. 2009, 77, $1723-1733$. [CrossRef]

55. Ghobashy, M.O.I.; Abu shady, H.M.; Rashad, S.S.; Shahlol, A.M.A. Klebsiella pneumoniae invasion, adherence and cytotoxicity are independent events mechanisms. Egypt. J. Exp. Biol. (Bot.) 2012, 8, 251-259.

56. Lamari, F.; Chakroun, I.; Rtimi, S. Assessment of the correlation among antibiotic resistance, adherence to abiotic and biotic surfaces, invasion and cytotoxicity of Pseudomonas aeruginosa isolated from diseased gilthead sea bream. Colloids Surf. B Biointerfaces 2017, 158, 229-236. [CrossRef]

(C) 2018 by the authors. Licensee MDPI, Basel, Switzerland. This article is an open access article distributed under the terms and conditions of the Creative Commons Attribution (CC BY) license (http:/ / creativecommons.org/licenses/by/4.0/). 